Western University Scholarship@Western

Centre for the Study of International Economic

Centre for the Study of International Economic

Relations Working Papers

Relations

1984

\title{
Comparative Advantage and International Trade and Investment in Services
}

Alan V.Deardorff

Follow this and additional works at: https://ir.lib.uwo.ca/economicscsier_wp

Part of the Economics Commons

Citation of this paper:

Deardorff, Alan V.. "Comparative Advantage and International Trade and Investment in Services." Centre for the Study of International Economic Relations Working Papers, 8441C. London, ON: Department of Economics, University of Western Ontario (1984). 
ISSN $\quad 0228-4235$

ISBN $0-7714-0591-X$

CENTRE FOR THE STUDY OF INTERNATIONAL ECONOMIC RELATIONS

WORKING PAPER NO. $8441 \mathrm{C}$

COMPARATIVE ADVANTAGE AND INTERNATIONAL

TRADE AND INVESTMENT IN SERVICES

Alan V. Deardorff

This paper contains preliminary findings from research work still in progress and should not be quoted without prior approval of the author.

DEPARTMENT OF ECONOMICS UNIVERSITY OF WESTERN ONTARIO LONDON, CANADA N6A 5C2

Department of Ecomomics Library
NOV 11984
University of Westem Ontario




\section{CURRENT ISSUES IN TRADE AND INVESTMENT IN SERVICE INDUSTRIES: \\ U.5.-CANADIAY BILATERAL AND MULTILATERAL PERSPECTIVES}

\section{THE THIRD ANNUAL WORKSHOP ON U.S. -CANADIAN RELATIONS}

Sponsored by the Institute of Public Policy studies of The University of Michigan and the Centre for the Study of International Economic Relations of the University of Western Ontario, with financial support from the Ford Foundation, Donner Foundation, National Science Foundation, Ontario Economic Council, Bank of Montreal, IBM Canada, and The Fishman-Davidson Center of the University of Pennsylvania.

October 19-20, 1984

Ann Arbor, Michigan

Alan $V$. Deardorff

The University of Michigan

Comparative Advantage and International

Trade and Investment in Services

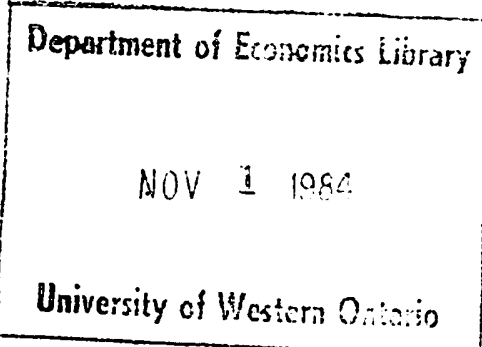




\title{
Comparative Advantage and International Trade and Investment in Services
}

\author{
by \\ Alan V. Deardorff \\ University of Michigan
}

Oetober 9,1984

For Presentation at the Third Annual Workshop on U.S. - Canadian Relations, "Current Issues in Trade and Investment in Service Industries: U.S.-Canadian Bilateral and Multilateral

Perspectives," October 19, 1984, Ann Arbor, Michigan.

*I wish to thank Robert M. Stern for his helpful comments and insights during the discussions which led to this paper. Helpful comments were also porvided by members of the Research Seminar in International Economics at the University of Michigan. 
Comparative Advantage and International Trade and Investment in Services

\author{
by \\ Al an $V$. Deardorff \\ University of Michigan
}

I. Introduction

My purpose in this paper is to evaluate the theoretical validity of the Principle of Comparative Aduantage as it applies to international trade in services. I will focus only on the positive issue of whether trade, if undistorted by policy, will conform to a pattern that is explainable by comparative advantage, and I will not treat, except tangentially, the welfare effects of such trade. Even so, as I will explain in a moment, it is probably impossible to provide a conclusive answer to the question of whether services trade follows comparative advantage. Instead, I will confine my attention to only a couple of distinctive characteristics of trade in services, and use these as the basis for theoretical models. Within these models I will show that, while there exist ways of defining comparative advantage and trade such that the Principle of Comparative Advantage holds quite nicely, there is nonetheless at least one case in which trade will appear to violate the Principle. Thus 
it is not clear that comparative advantage is necessarily the most useful eriterion for explaining international trade in services.

The difficulty that arises in evaluating trade in services -- and this applies to the problem in both its positive and normative aspects -- is the lack of consensus as to what constitute services. Most can agree on a list of real-world activities that are services, and with some exceptions there is no difficulty distinguishing them from goods. But it is harder to identify what it is economically that distirguishes all goods from all services, and then to use this difference as the basis for theoretical analysis.

At one extreme, economists are accustomed to lumping all goods and services together, assuming implicitly that there are no economically meaningful differences between them. It then follows of course that what is said of goods applies equally well to services, and in particular that the Principle of Comparative Advantage is as valid for services as for goods. But this follows tautologically from the failure to distinguish them in the first place, and it proves nothing. The opportunity remains for someone to point out what they regard as a crucial difference between goods and services and to object that this difference has not been taken into account. Without explicitly considering models of all possible characteristics that might distinguish goods and services, as well as all possible combinations thereof, 
one cannot claim to have proved one's case conclusively. Since there is no end to the list of characteristics that might be aduanced as distinguishing at least some goods and services, I conclude that the issue of this paper is one that can never be resolved once and for all.

On the other hand, just as we often know intuitively which things are goods and which are services, we also know intuitively that some of the differences between goods and services are unimportant for the issue of comparative aduantage. Hindley and Smith (1984) illustrate this in the following comment on the view that services have been ignored in theories of comparative advantage:

The underlying premise is that services are different from goods, which may indeed be so. But a bunch of flowers and a ton of coal and a jet airliner are very different things also. It may be true that no economist has discussed international trade in brussels sprouts or used that vegetable to illustrate comparative advantage. That surely does not raise any substantial question as to whether the conceptual and theoretical apparatus of comparative cost theory is applicable to brussels sprouts.

Even this, of course, presumes our agreement that the brussels sprout is just another vegetable. Were it known, instead, that brussels sprouts are addictive, or that their production fouls the environment, or that they are valued primarily as collectibles, then we might recognize that some of the postulates that are normally assumed in proving comparative advantage are violated by brussels sprouts, and we would not be so sanguine. 
Thus the only way to proceed on an issue like this, I believe, is piecemeal. Select, one at a time, various characteristics that distinguish services from goods, characteristics that intuition suggests may have a bearing on trade and comparative advantage. Build a model that can capture these characteristics and examine its implications. Finally, base one's conclusion, first, on a judgement as to the empirical relevance of those characteristics, if any, that do seem to undermine comparative advantage, and second, on the comprehensiveness of the list of characteristics that do not. In all, one must keep an open mind: there always remains the possibility that some other characteristic, so far unexamined, will be found to overturn the results.

In subsequent sections, then, I will follow this approach, examining in theoretical terms three separate characteristics that seem important for at least a portion of the international trade in services. The sections are largely independent, since different techniques turn out to be useful in each. I will try only at the end to tie them together in some fashion.

The first characteristic that I will consider, in section II, is also the least general: the fact that traded services often arise as a byproduct of trade in goods. While "trade services", such as transportation, cargo insurance, and trade financing, are not the only kind of services that are traded, there is reason to think that they fail to satisfy one of the 
standard assumptions of trade theory, and thus may make a reexamination of comparative advantage worthwhile. It turns out that comparative advantage continues to work quite well to explain such trade, but the exercise is nonetheless fruitful in providing other insights.

In Section, III I turn to another characteristic that is often regarded as more general, and also more likely to transcend comparative advantage. This is the fact that trade in services frequently requires, or is at least accompanied by, international direct investment. If comparative advantage explains only trade in goods, and if trade in services is really a form of trade in the factors of production, then one might question the relevance of comparative advantage for explaining trade in services. It turns out, however, that international factor movements are just as much the creatures of comparative advantage as is trade in goods. This is implicit in some of the theoretical writings on comparative advantage, and can be made explicit quite easily. Thus if services trade were really just a disguised form of international factor movement, it would still be determined by the Principle of Comparative Advantage.

However, it is my view that the characterization of services trade as factor trade is overly simple and perhaps misleading. In Section IV, therefore, I will suggest an alternative interpretation in which services are distinct from goods in terms of the location requirements of production. Loosely following 
Hill (1977), I will assume that while goods can be produced elsewhere from where they are consumed, services cannot. In contrast, however, and to make trade in services ras distinct from factors) possible in these circumstances, I will also assume that production of services is possible even though some of the factors of production from which they are produced are not present but instead make their contribution from a distance, perhaps even from a different country.

To formalize this concept, I look at a simple $2 \times 2 \times 2$ model in which one of the sectors is identified as producing a service. The labor in this sector can produce only for domestic demand, but the second input -- call it management -- can be provided from abroad. If we think of the ownership of the firm as abiding with management, then it is natural to think of the firm as exporting the service, even though the actual production takes place within the importing country using local labor. Since management itself does not move, one would not observe international investment occurring here cexcept perhaps if one were to infer such investment from the repatriation of earnings that are necessary to pay the managers at home). Furthermore, it turns out that, depending on the factor intensities of production in the two sectors, one can easily get a case in which the

1. One might be uncomfortable with the idea that managers never set foot in the country where production takes place. Presumably the presence of managers when a subsidiary is first established may be necessary, even if the subsidiary can function without them present later on. 
service is exported from a country in which it would have been relatively expensive in autarky, thus violating comparative advantage.

Before beginning, I should mention one characteristic of some services trade that I will not consider. I will not look at any models of imperfect competition, and even in section IV, where I model what might be viewed as multinational corporations, I continue to assume that these corporations behave competitively. My reason for this is twofold. First, I wish to give comparative advantage a fair chance of working, and existing models of trade even in goods have not established that comparative advantage is descriptively correct for all of the possible imperfectly competitive market structures. Presumably, if comparative advantage has difficulty in my competitive model, as it does in Section IV, then.it would have no less difficulty in a model of imperfect competition.

Second, while it is true that many of the multinationals that deal in services are too large to be regarded as competitive, this is equally true of those that deal in goods. Thus it is hard to see that imperfect competition is an identifying characteristic of trade in services per se. With that in mind, I prefer to look at the simplest models that do incorporate such identifying characteristics, and for this the competitive framework seems appropriate. 
II. Trade in Trade Services

Not all services are rendered directly to consumers. Many services are intermediate inputs to production, and some are inputs to other activities such as trade. Indeed, trade in goods ineuitably requires that goods be moved from one country to another, and the provision of that transportation is a service. In the modern world, other services too are used by traders, such as cargo insurance, trade financing, and legal help in dealing with different countries' regulations. Thus one can say that

- trade in goods constitutes a source of demand for a variety of services, which I will call trade services. 2

Now these trade services are not themselues inevitably traded. Exporters and importers could, if they wished, deal only with transporters, insurers, banks and lawyers from their home countries. But it is also natural for traders to be aware of the availability of these services from other countries, and thus one might expect trade in trade services to arise earlier in history than trade in services of other kinds and for other uses. Thus trade in trade services, if it is distinct at all from other forms of service trade, seems worthy of examination.

Furthermore, trade in trade services does have one very 2. These are services which stern (1984) calls complementary to
goods. 
special property that distinguishes it from other forms of trade: the demand for it arises solely from other trade. Why is this important for our discussion of comparative advantage?

A first reason is that comparative advantage is customarily measured in terms of autarky prices. Yet trade services by definition are not demanded in autarky, and therefore their autarky prices do not exist. Thus we must look elsewhere for an indicator of comparative advantage in trade services, and this alone makes them of some interest. One possibility, if the services are produced using factors of production which themselves have well-defined autarky prices, would be to measure comparative advantage in terms of their minimum costs of production at autarky factor prices. 3 Yet even this may be suspect, since the autarky factor prices in no way reflect the demands for them that may arise when they are used to produce trade services.

A second reason is that trade services violate an assumption that is often made in trade theory, and to the extent that demonstrations of comparative aduantage rest on that assumption, they need at least to be reconsidered. The assumption in question is that demand conditions are identical across

3. Another possibility, in some cases, would be to use the autarky prices of similar services that are used within the domestic market even in autarky. This may be misleading, however, since the requirements of international trade are often different from domestic trade. 
countries: i.e., that, faced with identical prices, consumers in different countries will demand goods in identical proportions. This assumption is sometimes used in proofs of the Heckscher-ohlin theorem, and when it is not, differences in demands are incorporated in comparisons of relative autarky prices. But as just noted, autarky prices are not obuiously available in the case of trade services.

There is a final problem that would seem on the face of it to cause problems: trade in trade services itself is not well defined. We are not accustomed in trade theory to worrying about where, in the process of trade in a good, the ownership of that good changes hands. But in defining trade in trade services this may make a difference. Consider, for example, the case of a good that is sold by a domestic exporter to a foreign importer, and that must be transported from one to the other. Suppose further that the transportation service is provided by a firm based in the importing country. 4 If that transportation is purchased by the importing firm, then the transaction involves no trade in transportation services. But if it is purchased by the exporting firm, our country will be regarded as importing these services. The actual production that takes place, including the production of the transportation service, is the same in both cases, but the recording of how much trade has occured is quite different.

4. Similar problems arise if transportation is provided by the exporting country or even by a third country. 
Clearly there are similar problems whenever a trade service is provided, since there are always two parties to the goods-trade transaction and either mar be the demander of the service.

What difference could all of this make for comparative advantage? A couple of interesting possibilities suggest themselves.

Consider, for example, a country with a cost advantage in providing transportation services. By the usual argument of comparative costs, this country should become a net provider of these services to the world, once trade is allowed. Suppose however that the country is very remote from world markets, and that as a result it is also an unusually great demander of transportation services, once it enters into trade. We mar then find it being an importer of transportation, in spite of its comparative cost advantage. Note too that the country's distance from world markets will not be reflected in its autarky costs of transportation, as would be the case if it had an unusual demand for a good or factor instead, since in autarky its demand for transportation is not revealed to any market.

A second difficulty that might be expected to arise from trade services has to do with the effect that restrictions on trade in services may have on patterns of trade in goods. Suppose, for example, that a country has a comparative advantage in a particular good that happens to require a large dose of some trade service, say insurance, if it is to be traded. This in 
itself need not interfere with its exporting the good, so long as all countries pay the same price for trade insurance. But suppose instead that trade in insurance is not permitted and that the country has a strong comparative disaduantage in providing this service. Then the cost to it of exporting, should it be required to insure its trade itself, could be prohibitive of its exporting the good at all. Thus it appears that acknowledging the existence of trade services in a model of trade in goods may alter what we can say even about the latter.

In fact, however, trade in trade services does not make as much difference for comparative advantage as all of this suggests. To see this, I introduce the following formal model.

Consider a world of $n$ countries and $m$ goods and let there be also services that will be useful only if there is trade in goods. In vectors of appropriate lengths, and omitting implicit country superseripts, let $X$ be a particular country's outputs of goods, $C$ its final demands for these goods, and thus $T=X-C$ its net exports of goods. Similarly, let $S$ be the trade services it produces, $U$ the trade services that it uses in the course of trade, and $U=S-U$ its net exports of trade services.

In order to characterize the technology of production and trade, I must first define the physical meaning of trade, and as I have done before in Deardorff (1980) I will make use of the convenient fiction of a single world port. That is, suppose that there exists a single point on the globe through which all trade 
must pass. Further, to avoid the ambiguity mentioned above in the definition of trade in trade services, I will assume that each country's own traders are responsible for getting its good to and from the world port, so that if a foreigner provides trade services between a country and the port, this will be regarded as imports of those services. 5 These assumptions are not as restrictive as they seem, as I argued in the appendix to Deardorff $(1980)$.

Technology can now be defined quite simply. For production, let $F=\{(X, S)\}$ be the set of all feasible outputs of goods and services that can be produced by a country given its technology and factor endowments. It is a production possibility set of the usual sort, and it admits negative values for elements of $X$, representing the net use of goods as intermediate inputs. Only nonnegative values of $s$ are in the set, however, since the services here are useful in trade only, and not in domestic production. The manner in which they may be used is described by another set, $G=\{(T, U)\}$, the set of all possible vectors of net trade in goods and (nonnegative) vectors of trade services used. If a particular service, $U_{1}$, were required in fixed proportion to the amount of trade in a particular good, $T_{1}$, for example, then a

5. A more realistic but more cumbersome specification would be to define all trade services produced as exported and all trade services used as imported, since trade statistics typically measure a country's trade from its own border. Obuiously the results here, which relate to net trade, would be unaffected by this specification. 
cross-section of the set $G$ would be as indicated in Figure 1. That is, $U_{1}$ must be at least as great as the appropriate constant times the abolute value of $T_{1}$. In general, of course, more complicated shapes are possible, and I assume only sufficient boundedness on the technology to make the releuant maximization problems possess solutions. These sets, F and $G$, may differ in general from country to country.

I turn now to characterization of equilibria, making such assumptions, familiar in trade theory, as perfect competition, the weak axion of revealed preference, profit maximization, and balanced trade. I will consider only three types of equilibrium: Autarky, in which there is no trade in either goods or services; Free Trade, in both goods and services; and what I will call Semi-Autarky, in which there is free trade in goods but no trade at all in services, so that, for example, each country's own transportation firms must move its exports to the port and its imports from the port. More general cases of nonprohibitive tariffs and other restrictions on the two kinds of trade could easily be allowed with additional notation.

An autarky equilibrium consists of (vectors of) prices of goods, $p^{a}$, prices of services, $q^{a}$, and outputs of goods, $x^{a}$, which are feasible to produce, which are demanded by consumers facing these prices, and which maximize the value of the country's output: 


$$
p^{2} x^{2} \geq p^{2} x+q^{2} s \text { for all }(x, s) \in F
$$

Note that, while the output of trade services is zero in autarky equilibrium, we can still speak of equilibrium prices for these services, as long as these are prices at which profit-maximizing producers of services would be content not to produce. However, since negative values of $S$ are excluded from $F$, this is likely to mean that these prices are not unique. Indeed, for any equilibrium that satisfies $(1)$, any other prices of services not greater than $q^{2}$ will also be an autarky equilibrium.

A free trade equilibrium is somewhat more involved. It consists, for a given country, of both domestic and "world" prices, $p^{d}$ and $p^{w}$, the latter being the prices of goods at the international port, plus world prices of services, $q^{W}$, as well. In addition, there are quantities of goods produced and consumed, $x^{f}$ and $c^{f}$ respectively, and quantities of services produced and used, $s^{f}$ and $u^{f}$, as well. To be an equilibrium, all of these quantities must be feasible, the goods consumed must be willingly demanded at the prices $p^{d}$, and production and trade must yield as great a value as any other available opportunity. Thus

$$
p^{d} x^{f}+q^{w} s^{f} \geq p^{d} x+q^{w} s \text { for all }(x, s) \in F
$$

and

$$
\begin{aligned}
\left\langle p^{w}-p^{d}\right) T^{f}-q^{w} U^{f} \geq\left\langle p^{w}-p^{d}\right) T-q^{w} U & \\
& \text { for all }(T, U) \leqslant G
\end{aligned}
$$

Finally, I require balanced trade: 


$$
p^{w} T^{f}+q^{w} v^{f}=0
$$

To complete the specification of the free trade equilibrium, I would need the requirement that world markets clear for both goods and services. I would also note that world prices of goods and services are the same for all countries, while domestic prices need not be.

A "semi-autarky" equilibrium, as described above, requires essentially the same conditions as (2), (3) and (4), though in this case the quantities of services produced and used, call them $s^{5}$ and $U^{3}$, must be the same, and the prices of services, $p^{s}$, can vary across countries. I will not bother to write down the analogous conditions.

I am now in a position to examine the role of comparative advantage in these equilibria. As in Deardorff (1980), the crucial relationship is the value of trade at autarky prices. Since this value is the inner product of the vector of net trade with the vector of autarky prices, its sign turns out to give us various correlations between autarky prices and trade. And it is easy to show, much as in Deardorff (1980), that

$$
p^{a} T^{f}+q^{a} U^{f} \leq 0
$$

To see this, first note that

$$
\begin{aligned}
p^{d} c^{a} & =p d^{a} \\
& \leq p x^{f}+q^{w} s^{f} \\
& \leq p x^{f}+q^{w} S^{f}+\left[\left(p^{w}-p^{d}\right) T^{f}-q^{w} U^{f}\right]
\end{aligned}
$$




$$
\begin{aligned}
& =p^{d} c^{f}+p^{w} T^{f}+q^{w} U^{f} \\
& =p^{d} c^{f}
\end{aligned}
$$

where the first inequality follows from (2), the second inequality follows from ( 3 ) using $T=U=0$ on the $r i g h t-h a n d-s i d e$ of (3), and the last two equalities use the definitions, $T=X-C$ and $V=S-U$, and equation (4). Relation ( 6 ) says that free-trade consumption is revealed preferred to autarky consumption, and thus the weak axion of revealed preference implies that

(7) $\quad p^{a} c^{a} \leq p^{a} c^{f}$

Finally, the autarky value of trade can be evaluated as follows:

$$
\begin{aligned}
p^{a} T^{f} & +q^{a} u^{f}=p^{a} x^{f}+q^{a} s^{f}-p^{a} c^{f}-q^{a} u^{f} \\
& \leq p^{a} x^{a}-p^{a} c^{f}-q^{a} u^{f} \\
& =p^{a} c^{a}-p^{a} c^{f}-q^{a} u^{f} \\
& \leq-q^{a} u^{f} \\
& \leq 0
\end{aligned}
$$

where the first inequality follows from (1), the second from ( 7 ), and the 1 ast from the fact the both $q$ and $U$ must be nonnegative vectors. This completes the proof of (5).

The inequality in (5), then, establishes that the Principle of Comparative Advantage holds in this model of trade in both goods and trade services. That is, it must be true on average that the goods and services that a country exports must be worth less to it in autarky than the goods and services it imports. of 
course, this average relationship permits individual goods and services to be traded in ways that seem contrary to comparative aduantage, and thus some examples such as I discussed above are possible. But there is nothing special about services in this respect: similar examples can be found also for trade in goods alone, as I showed in Deardorff (1979). Thus it seems that this particular characteristic of trade in services - the fact that much of it is demanded only as a byproduct of trade in goods -does not after all undermine the usual result of comparative advantage.

There is, however, a bit more that one can say in this particular model.

First, recall that the "autarky prices" of services that appear in (5) are to a large extent arbitrary. Given any prices for which (2) holds, (2) will also hold if these prices are replaced by prices of services that are closer to zero, and even if they are replaced by zero itself. Thus it follows as a corrolary to (5) that

$$
p^{a} T^{f} \leq 0
$$

This looks exactly like the traditional result from a model without services, but it applies to this model in which the trade in goods that is included in $T$ is only a part of the trade that is going on. Thus the Principle of Comparative Aduantage, it turns out, applies to trade in goods alone, even when trade 
services are also being traded.

There is yet another corollary that follows in turn from (9). It is possible in general for a country to exchange goods for services and vice versa. But in a model like this in which all services are trade services, it is impossible for there to be net trade in just one good in exchange for services. For if there were, then $\mathrm{p}^{2} \mathrm{~T}^{f}$ would be positive for the country that exports the good, violating (9).

Finally, consider what would happen in a "semi-autarky" equilibrium, in which there is trade in goods but not in services. All of the conditions used above still apply, with the superscript "f" replaced by "s". Thus the result in (5) continues to hold in a semi-autarky equilibrium, and

$$
\text { (10) } p^{2} T^{5} \leq 0
$$

since $U^{S}$ is zero by definition. Thus comparative advantage continues to explain trade in goods, even if trade in traded services is not permitted. Euidently, my example above, of how prohibiting trade in services might undermine a country's comparative advantage in a good that it finds expensive to trade, indicates only how trade can be reduced or eliminated by this phenomenon, but not that its pattern can be reversed. 6

6. Note that $(10)$ is consistent with $T^{s}=0$. That is, even though trade in goods is permitted in semi-autarky, it may be that none will occur, if the costs of domestically produced trade services turn out to be prohibitive. 
To conclude this section, then, allowing for trade in trade services leads to some interesting possibilities as far as the trade in particular goods and services may be concerned, but it does not in any way undermine the Principle of Comparative Advantage as the general indicator of the patterns of trade that can take place. On the contrary, the Principle is strengthened in a sense, for it now applies even to the subcategory of trade in goods alone, as well as to trade in goods and services toge ther. 
II Services Trade as International Factor Movements

A notable feature of much of the trade in services is that it may require a presence, on the part of the exporting firm, within the importing country. This means that some employees of the exporting firm may have to be present to administer, market, or oversee the service. Or it may mean the need to establish a physical plant in which or from which the service can be provided in the importing country. Either way, this suggests the need for 1 abor, capital, or both to move from the exporting country to the importing country in order to prouide the service. I will argue in the next section that such factor movements are not in fact an inevitable feature of trade in services, but they certainly can occur in conjunction with it and have been identified by many as a crucial aspect of services trade. Therefore it seems sensible at this point to ask whether factor movements do give reason to doubt the validity of comparative advantage as it applies to services.

The answer, fortunately, is easily found. Quite independently of whether they involve services or not, international factor movements fit neatly into the theory of comparative advantage. It is true, of course, that factor movements can reduce -- even to zero-- the amount of trade in goods that occurs in response to comparative aduantage. But it is also true that trade in goods and factors together conforms to 
the Principle of Comparative Aduantage in the usual sense that those goods and factors that are exported will, on average, have been cheaper in autarky than those that are imported.

It is unnecessary to prove this result here since it has appeared elsewhere. In my own (1980) article, this result was implicit, since the "goods" in that model were defined to include "all final goods, intermediate goods, and services of primary factors of production," any or all of which could be traded or nontraded. The result has also been made explicit by Ethier and Svensson (1983) as one of many theorems of trade theory that they extend to a model with factor mobility.

Thus, to observe that trade in services often involves international direct investment, for example, in no way suggests that it should therefore fail to conform to comparative advantage. On the contrary, if the export of certain services requires the export of capital, then one would expect the countries that export these services to be also those in which capital is relatively cheap. Similarly, if other services require the movement of certain types of labor in order for them to be traded, then those countries where this labor is readily auailable will be the most likely to export them.

As always in general discussions of trade patterns, one can find cases in which particular goods, services or factors appear to be traded perversely. This is usually either a result of the greater importance of some other determinant of relative costs, 
or the result of some form of complementarity with another good or service. For example, suppose that a service relies heavily on both skilled and unskilled labor, and is relatively expensive in the U.S. because the scarcity of the latter outweighs the abundance of the former. If trade in the service requires that only skilled labor move internationally, the necessary unskilled labor being taken from the local labor market in the importing country, then one could easily find the service being exported by the U.S. in spite of its relatively high autarky cost here. In this example, the trade in the service alone appears to run counter to comparative advantage, but the trade in goods and services together, including the trade in skilled labor, would not. A proper evaluation of comparative advantage requires only that we succeed in taking into account all of the trade that is actually taking place.

On the other hand, this example is very similar to the situation that I will describe in the next section. For suppose that the skilled labor just mentioned could make its contribution to production without actually moving to the country to which the service is being exported. Trade in the service would continue to occur as just deseribed, but trade in skilled labor would not. Since the trade in the service is what appeared perverse, we would then be left with an apparent violation of comparative advantage without any offsetting trade in factors. Thus it may not be movement of factors internationally, but rather the possibility that they need not move in order to make a 
contribution; that causes the greatest difficulty for the Principle of Comparative Advantage as it applies to services. This is what I will examine more formally in the next section. 
IV. Service Trade with Absent Factors

I noted above the tendency for service trade to require the presence of the service exporting firm in the importing country. This is a general property of services trade, especially if one follows Hill (1977) in defining services as marketable activities in which production must take place in the presence of the demander. Hill argues that services in general cause a change in either the person or the property of the consumer of the service. If the change is in a person, then obviously that person must be present during production, but even if the change is in some good owned by the consumer, the need to maintain that ownership intact during whatever tranformation occurs makes it unlikely that production can take place too far removed from the consumer. In any case, I will from now on let this property be one of the defining characteristics of a service: that its production must take place in the same location for at least the same country) as is occupied by the person or firm that purchases it.

Now in Section III, this characteristic led to the association of services trade with international factor movements, on the assumption that a firm can produce in a foreign country only if it also moves some of its factors of production there. But this is not a good assumption, as recent observation of the behavior of multinational corporations makes clear. To 
produce in a foreign country, a firm needs to employ factors of production there. But these need not be factors that it brought from its home country; they can be hired on local factor markets. Indeed for many years we trade theorists felt that we had covered the subject of multinational enterprises implicitly in our studies of international capital movements, and only recently have we explicitly recognized that such enterprises typically organize much of their financial and other activities locally, in the same countries where they produce. Furthermore, even when they do raise funds on international capital markets, their decisions are truly international, and have little to do with where their home offices are located.

Thus a firm which wishes to "export" a service may do so by setting up a branch in a foreign country, hiring local labor, and financing any necessary local capital expenditures within the local market of the foreign country as well. If it does all of this, one may then wonder what it is that is actually being exported. The answer in general is that there is some other factor that contributes to the profitability of the firm. This may be a unique method of management, a proprietary product or brand name, or a technique of production to which only it has access. In any case, if the "export" of the service is truly an export at all, there must be something that is provided by the home office of the firm that contributes to its profitability. otherwise, it would pay its entire revenue to local factors, and no international transactions would take place at all. 
To capture this idea I will follow Markusen (1984) and Helpman (1984) in their models of multinational corporations, and assume that production of services requires inputs of at least some factors that need not be physically present at the same location where production takes place. These "absent factors" can encompass all of the contributions described above that a multinational can make to its subsidiaries, but for ease of reference I will, from now on, simply call them management.

Markusen and Helpman both go well beyond what I want to do here, in their pursuit of explanations for multinationals. For one thing, they make no distinction between goods and services, and their multinationals may implicitly produce both. In addition, they assume that what I am calling absent factors are also, in a sense, public goods within the firm, which is able to provide services to additional numbers of subsidiaries without additional effort in the home office. This in turn leads them also to assume that multinationals are large and noncompetitive. I will.make neither of these assumptions, since I do not view imperfect competition as more likely for services than for goods, and I want therefore to remain in an environment where small competitive firms are possible. Thus my factor, management, is just like any other factor in a neoclassical production function, except that it can be located away from where production of services takes place.

Notice, then, the dichotomy that I am assuming in the 
technologies of goods and services. Production of goods, 1 assume, requires the simultaneous presence of all factors of production, but does not require the presence of those who will consume, or otherwise use, the goods once they are produced. Services, on the other hand, do require the presence of consumers, but do not require the presence of all factors of production. Naturally, real world activities are not so clearly separated. There are services in which there is no absent factor contribution, but these can be dispensed with as unable to enter international trade. There are also goods that can make use of absent factors, and this could complicate the analysis a bit since their location of production might then be indeterminant. But it will be convenient here to consider only the two extremes.

\section{In fact, what seems to be crucial for the results that} follow is not that some factors can be absent, but rather that some factors must be present, and that for services this presence must be in the same location as the consumer of the service. Since goods can be transported, it is hard to think of examples of exports of goods for which some factor of production must be present in the importing country.

To show what this view of goods and services can imply for

7. On the other hand, Bob staiger has pointed out to me that local content legislation has precisely this effect. It is interesting to speculate whether, given the findings below, such legislation can undermine comparative aduantage even in goods. 
comparative advantage, I turn now to a very simple model of international trade that incorporates this view. The model is like the standard textbook Heckscher-Ohlin (H-O) trade model of two goods, two factors, and two countries. However, in this case I make one of the goods a service, and require that it be produced where it is consumed. Further, as just explained, I call one of the two factors of production management, and let it contribute to services production in absentia. Otherwise the assumptions of the model are exactly those of the H-O model.

In autarky this model looks exactly like the H-O model. Since autarky constrains all factors, production, and consumption to locate within the same closed country, the special location requirements of services are unimportant. Thus, for example, the autarky relative price of the service will depend on demand for the service relative to the good, the endowments of the two factors, labor and management, and the intensities with which these two factors are required in production of the good and the service. In particular, comparing two countries, $A$ and $B, I$ will assume that the autarky relative price of the service is lower in A than in B. With identical homothetic demands and identical technologies, this could either mean that services are management intensive and that $A$ has a relative abundance of management, or that services are labor intensive and $A$ is well endowed with labor. Alternatively, the price difference could result from differences in technolagy. In any case; A has a comparative advantage in services by the usual criterion of relative autarky 
prices, and we wish to see whether this aduantage is reflected in its trade, once trade is allowed.

In the H-O model, free trade equates the prices of traded goods across countries. This in turn equates factor prices across countries as well, if the other assumptions of the factor-price-equalization theorem are satisfied, in particular if technologies are identical and if both goods are produced in both countries. In the model here, things are different, but the outcome may be the same.

Free trade directly equates the price, across countries, of only the good, not the service. If the producer of a service were to observe a higher price abroad than at home, that in itself would not induce it to export, since to serve the foreign market it must produce there and must employ at least some local factors. The fact that it can produce more cheaply at home using domestic factors is of no help, since those factors cannot in general be used for production abroad.

On the other hand, I assume that one of the domestic factors, management, can be used for production abroad, since it is not required to be present where production takes place. Under what circumstances, then, will a service firm be able to compete successfully aboad? obviously the answer depends on technology and the price of management in the two countries, not on the price of the service itself. If management is cheaper in A than in B, and if technologies are everywhere the same, then 
producers from A will be able to undercut the prices charged by producers in $B$, since they will have access to the same 1 abor market in $B$, but will be able to use cheaper management. In fact, the same would be true for producers in $B$, were we to permit them to hire managers from $A$, but I will assume that the identity of the firm lies with its managers and exclude this possibility.

Continue to assume, for the time being, identical, constant-returns technologies. Clearly, then, trade in services will take place, if it is permitted, whenever the price of management differs between the countries. This could lead to specialization of various sorts, all of the services in $B$ being provided by $A^{\prime} s$ firms, for example. But if it does not, then such trade will equate the prices of management in the two countries, just as trade in a good equates the price of the good. Further, once the price of the one good and the price of the one factor, management, are equated across countries, then the logic of the factor-price-equalization theorem will work to equate the remaining prices: those of the other factor, 1 abor, and of the service. Thus free trade will tend to equate the price of services in the two countries, but not because of. arbitrage in the markets for services themselves. The requirement that services be produced where they are consumed prevents such arbitrage. Instead the prices of services are equated indirectly, just as factor prices are equated in the H-O mode 1 . 
Formally, let the countries produce a good, $X$, and $a$ service, $S$, using factors of production 1 abor, $L$, and management, M. Prices of the good, $P$, and of the service, $q$, will equal the minimum unit costs of whatever firms produce them, and these costs are functions of the wage of labor, $w$, and the salary of management, s:

(11)

$$
p=c_{x}(w, s) ; \quad q=c_{s}(w, s)
$$

where each of the four prices should bear appropriate superscripts to indicate which country's good, service, and factors are being described. With free trade in the good, we must have $p^{A}=p^{B}$, and thus, if the good is produced in both countries,

$$
p^{A}=c_{x}\left(w^{A}, s^{A}\right)=c_{x}\left(w^{B}, s^{B}\right)=p^{B}
$$

With free trade in the service industry, $A^{\prime}$ s producers will

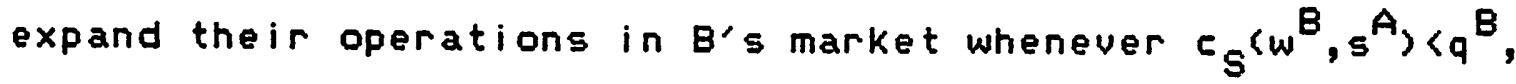
since they can use their own managers but $B^{\prime} s$ workers. If in equilibrium producers from both countries continue to serve $B^{\prime} s$ market, this relationship must hold with equality, and thus

$$
c_{s}\left(w^{B}, s^{A}\right)=c_{s}\left(w^{B}, s^{B}\right)
$$

which, given the nature of the unit cost functions, will be true only if

$$
\text { (14) } s^{A}=s^{B}
$$


Similar reasoning implies (14) if service producers from both countries share $A^{\prime}$ s market, so that it is only if a single country's producers take over the provision of services in both countries that salaries will fail to be equalized.

Furthermore, once salaries are equalized, it follows from (12) that wages will be equalized as well, and then from (11) that prices of services will be equalized. Thus, with incomplete specialization, free trade in this model implies complete factor price (and service price) equalization, much as in the $\mathrm{H}-\mathrm{O}$ model.

This is a convenient result, since it means that all prices in a free trade equilibrium will be the same as would obtain in an "integrated world economy," as that term is used by Helpman and Krugman (1984). That is, if all goods, services, and factors were internationally mobile, then their prices would be the same worldwide and would be set so as to equate world supply and demand for each. These same prices will be equilibrium prices with free trade, even though factors and services cannot move, so long as it is possible to allocate production activities across countries in such a way as to maintain the incomplete specialization that is needed for factor price equalization. These prices provide a convenient benchmark, since they are also those that would prevail with factor-price-equalization if the model did not impose special location requirements on the service industry and thus were identical to the familiar H-O model. 
In order to examine further the nature of the free trade equilibrium, it is helpful to use diagrams. In Figure 2, I show the two countries' transformation curves between $X$ and $s$ as they would appear if both countries were to use their labor and management only in domestic production. These are conventional transformation curves, and I have drawn them to reflect my assumption that country $A$ has an apparent comparative aduantage in services. Thus if services could be traded directly, a world relative price of services, $q^{f}$, would prevail in both countries. 8 Production and consumption would take place at points $H$ and $C$ respectively, and $A$ would export $S$ to $B$ in exchange for $x$.

In the present model, such direct trade in services is not possible, but if there is factor price equalization as just described, the same price, $q^{f}$, will clear the market. To make this possible, some of the management in one of the countries will be withdrawn from production of domestic services, and put into use instead as an absent factor in production of services abroad. While the factor does not actually move internationally, the production possibilities in the two countries will be affected exactly as if it did.

Which country's management will do this? To determine this, one could either look at the autarky prices and the incentives

8. I am now taking the price of the good as numeraire, $p^{A}=p^{B}=1$. 
they provide, or look at the changes in output that take place as production possibilities shift and see if they take us towards or away from equilibrium. Fortunately, both approaches yield the same result, as the reader can verify. But the result does depend on relative factor intensities, and so I now consider two cases. A third case, with unequal technologies, will follow.

\section{Case 1: Services are Management Intensive}

In this case, for $A$ to have the assumed comparative advantage in services, it must also have a relative abundance of the factor, management. Thus in autarky, the salary of managers in $A$ would be less than that in $B$, and there would be an incentive, as described above, for $A^{\prime}$ s service producers to "export" services: they will set up operations in B and provide services using labor that they hire in B, while continuing to use managers that are located within $A$. These managers, while they remain physically in $A$, are no longer contributing to production there, and $A^{\prime} s$ production possibilities contract exactly as though the managers had moved abroad. As a result, $A^{\prime} s$ transformation curve shifts inward in Rybczynski fashion. At the constant relative price, $q^{f}, A^{\prime} s$ production point in Figure 2 will move to the left and upwards, following the Rybczynski line $R^{A}$. Likewise, as these managers begin to contribute to production in country B, that country's production possibilities will expand and its production point will follow the parallel Rybezynski line, $R^{B}$, down and to the right. 
When will this process end? since services must be produced where they are consumed, it will end when the outputs of services in both countries exactly equal what the countries' own consumers demand. Thus the equilibrium is found in $A$ and $B$ along the Rybczynski lines vertically below and above, respectively, the consumption points, $c^{A}$ and $c^{B}$.

In this equilibrium, country $A$ imports good $X$, paying for it with what it earns from the provision of services in country B's market. These services, which amount physically to the quantity $S_{2}-S_{1}$ in Figure 2, are worth a good deal more than the imports of $x$ that $A$ gets in return. The difference, of course, is paid to labor in country B.

It is a bit unclear how one should measure what is going on here. It seems clear that country A is exporting services, but what is the quantity of services that is being exported? If we measure it as the total produced abroad, $S_{2}-s_{1}$, then we either appear to have unbalanced trade or we must say in addition that service firms in A are importing 1 abor from $B$. The latter is peculiar, since $B^{\prime}$ s workers are neither moving to $A$, nor providing input to production there. Alternatively, one could measure the export of services by the amount that the service firms repatriate, and which they use in turn to pay their managers. This, in units of services, is $S_{3}-s_{1}$ in Figure 2 and is equal in value to the imports of $x$, but it gives the appearance of measuring an input rather than an output. Finally, 
one could give up trying to measure trade in services at all, on the grounds that services cannot, strictly speaking, be traded, and measure instead the export of factor services -- management in this case - that is.taking place implicitly within the service firms. This would give the same value as the second al ternative.

In any case, whatever its amount, if there is trade in services here at all, it is clearly A that is doing the exporting. This is not surprising, since I assumed at the outset that $A$ had a comparative advantage in services. But in fact comparative advantage has nothing to do with this result, as the next case I consider will make clear.

Case II: Services are Labor Intensive

If services are labor intensive, then country $A^{\prime} s$ assumed low relative price must be the result of an abundance of labor. This case is shown in Figure 3 , where the transformation curves and free trade price 1 ines are the same as in Figure 2 . What is different is the incentive for trade in services.

As a result of its abundance now of labor, it is the wage, not the salary, that must be relatively lowest in $A$ in autarky. Attempts therefore by $A^{\prime} s$ service producers to penetrate $B^{\prime} s$ market will be frustrated, since they will find themselves employing $B^{\prime} s$ more expensive labor as well as their own more expensive managers, the worst of both worlds. Instead, it is $B^{\prime} s$ 
producers of services that will have the incentive to trade, and they will begin to use their managers together with $A^{\prime} s$ labor to produce services in $A$.

This causes $A^{\prime}$ s production possibility curve this time to shift outward, and $B^{\prime} s$ to shift inward, their production points as before moving along Rybczynski lines until markets are cleared. But this time, since services are now 1 abor intensive, these Rybczynski lines are steeper than the transformation curves rather than flatter, and the equilibria in Figure 3 are found above $C$ in $A$ and below $C$ in $B$. This is as it should be, since $A$ is now importing services, paying for them in part with its own labor, and in part with its exports of the good, $x$.

Thus we have a case in which trade in services appears to run counter to comparative aduantage. Labor-scarce country $B$ exports labor intensive services in spite of the fact that these services cost more in $B$ than in $A$ in autarky. The reason for this result is the fact that direct competition in the service industry is ruled out by the need to produce in the presence of consumers, together with the inability to move labor internationally. Instead, the only thing that matters for this kind of trade is the price of the only factor whose services can, in a sense, be traded: the factor I have called management whose productive services can operate from a distance. Since management is the abundant factor in $B$, this pattern of trade makes sense. 
Whether this pattern of trade should in fact be thought of as violating the Principle of Comparative Aduantage is another question, however. It turns out that by carefully reinterpreting what we mean by the Principle, we can assure that it remains valid even in this model.

One possibility, in line with the third method of measuring trade mentioned above, would be to say that services are not being traded at all, and that what really is being traded is the productive contribution of the factor, management. Since in both cases I and II considered above, services are exported by the country in which management has the lower relative autarky salary, trade then follows comparative advantage.

Another possibility, more in line with modern interpretations of the generalized Heckscher-ohlin model, is to focus not on trade itself but on the factor content of that trade. In that case, since the activity of producing the service abroad incorporates a contribution from only one domestic factor, management, the factor content of that trade is exclusively management. It follows again that each country tends to export, in factor content terms, its abundant factors.

Unfortunately, neither of these interpretations is particularly useful when it comes to explaining what is commonly meant by trade in services. For that, the model of this section has to suggest that the Principle of Comparative Aduantage is of little use, largely because in this model trade in services is 
not trade in the conventional sense.

\section{Case III: Differences in Technology}

A final case should be briefly considered, since it casts doubt on even the successful interpretations of comparative advantage mentioned above. Suppose that factor endowments are the same in the two countries and that autarky prices differ instead because country A has a different technology for producing services than does country $B$. There are many ways that technologies could differ, and the nature of the difference can be important, as is well known even in the conventional $\mathrm{H}-\mathrm{O}$ mode1.9 I will assume simply that A has a Hicks-neutral technological advantage in the industry. It is also important, in this model, whether the superior technology continues to be available to a firm if it produces abroad. There are some interesting possibilities here, but I will assume that a country's managers know their technology, so that its use abroad is possible. 10

Consider first how the autarky equilibria in the two countries will compare. If the two countries were to face the

9. See Findlay and Grubert (1959), for example.

10. With this in mind one might prefer to think of the technology as embodied in the managers, so that it would be factor-augmenting instead of Hicks neutral. I do not believe that alternative specifications of the technological advantage would make much difference for the point that I wish to make here. 
same prices, A would clearly produce more services and less goods than B. If demands are identical, it follows that the autarky price of services in $A$ must be lower than in $B$, and thus that the relative amount of services that is produced and consumed in $A$ will be greater than in B. What this means for factor prices depends both on the degree substitution between goods and services in demand and on the relative factor intensities of the two industries. 11 It is enough to consider one possibility. It may be that the salary of management in $A$, measured in units of $X$, is higher than in $B$, but by less than the full extent of $A^{\prime} s$ technological advantage.

If that is the case, then when trade is permitted, A will clearly export services to B. For A's producers have a superior technology, and their managers, though paid more than managers in B, are not paid enough to offset their firms' competitive edge.

Now this is as far as we need to go to see the implications of this example for comparative advantage. On the one hand, comparative advantage in the usual sense now seems to be working quite well: A is exporting services, which it produced more cheaply than B in autarky. On the other hand, consider the

11. If preferences were Cobb-Douglas, for example, $A$ and $B$, with their identical factor endowments, would produce the same amount of the good, $X$, in autarky and factor prices would be the same in the two countries in units of $x$. If the elasticity of substitution in demand is other than one, on the other hand, demand for $X$ will be either larger or smaller in $A$ than in $B$, and factor prices will differ also, in accordance with the relative factor intensity of $X$. 
alternative interpretations of comparative advantage that were used above to reconcile Case II with comparative advantage. In this case the autarky price of management is higher in $A$ than in $B$, but with trade it nonetheless appears to export the services of management. Thus the suggestion above that this model really involves trade in management, not services, and that this trade is in accord with comparative advantage, fails to work once differences in technology are introduced.

Summary of the Cases

Note, then, what these three cases together suggest about the validity of various versions of the Principle of Comparative Aduantage:

VERSION 1: Countries tend to export those goods and services for which their relative autarky prices are lowest. - This version is false in Case II above, where services make intensive use of the factor which must be employed locally where the service is provided. The reason is that a low autarky price in this case primarily reflects the cheapness of this factor at home, and this is of no use in exporting the service.

VERSION 2: Countries cannot trade service outputs, since these must be produced where they are consumed, but can only trade those inputs to the production of services whose contribution can be made internationally. Thus countries 
tend to export those goods and those international service inputs for which their relative autarky prices are lowest. - This version is true in both Case I and Case II above, where countries share identical technologies. But if technologies differ, as in Case III, then this version is no longer necessarily true. Service inputs (management) may be highly paid as a result of a technological aduantage, and may nonetheless, because of that advantage, be able to compete in producing services abroad.

VERSION 3: In terms of the factor content of trade, countries tend to export those factors (embodied in both goods and services) for which their relative autarky prices are lowest. - This version, like version 2 , is true in both Case I and Case II, but may be false in Case III.

Thus no version of the Principle of Comparative Aduantage that I have been able to find is valid in all three cases. It is interesting that version 3 is a form of what is usually regarded as the Heckscher-ohlin Theorem, rather than the Principle of Comparative Advantage. Since we have always known that the $H-O$ Theorem is valid only with identical technologies, one can say that it is made no less valid by introducing services. On the other hand, the conventional Principle of Comparative Advantage, which version 1 probably comes closest to expressing, has been 
presumed to be much more generally true than the H-O Theorem. 12 Thus it seems that allowing for services in the manner done here has much more serious implications for comparative advantage than it does for the factor proportions theory as embodied in the $\mathrm{H}-\mathrm{O}$ theorem.

12. Compare the treatments in Deardorff (1980) and Deardorff (1982). 
v. Conclusion

I have looked in this paper at three different characteristics of trade in services, to see in each case what they suggest for the validity of the Principle of Comparative Advantage. These characteristics were, first, that traded services often are demanded as a byproduct of trade in goods; second, that trade in services often goes hand in hand with international movement of factors; and third, that services may be provided internationally by transnational firms, some of whose factors of production make their contributions from a distance. The first two of these characteristics, I argued, do not in any way undermine the usefulness of comparative advantage in explaining trade, but the effect of the third is more troublesome. While it may be possible to reconcile trade with comparative advantage in this case, to do so requires a reinterpretation of trade in a way that interferes considerably with the usefulness of comparative aduantage as a guide to empirical reality. Furthermore, when comparative aduantage results from differences in technology rather than differences in factor endowments, then the reinterpretation actually makes matters worse. I am left with the uneasy feeling that the Principle of Comparative Advantage may not be as robust as many, including myself, have thought.

The question remains as to whether the model of section IV 
which led to this conclusion has any validity itself. That many corporations transcend national boundaries is clear, and that activities in the home office might contribute to the productivity of subsidiaries seems to me to be eminently reasonable. The particular form assumed for this contribution in the model of Section IV is of course far too simple, but as an illustration of how this phenomenon might matter for trade, I feel it is appropriate. In any case, I look forward to the impressions of others as to the usefulness of the approach taken here.

I do find the troublesome Case II of section IU especially interesting because of the way it seems to correspond to reality in one sense. It has been observed that services tend to be relatively expensive in the U.S. relative to the world at large. 13 Nonetheless, as is evident from the U.S. concern with trade liberalization in services, many regard the U.S. as at least a potentially important exporter in these industries. Now admittedly, this apparent contradiction of comparative advantage may result entirely from an aggregation problem: the particular services which we are likely to export are quite different from the bulk of very labor intensive services that even the U.S. would be more than content to see remain largely nontraded or restricted. But it is interesting that country B in the Case II

13. See, for example, Stern's (1984) contribution to this conference. 
example was also a labor scarce country and that it nonetheless could profit from exporting services that were, in comparison with goods, labor intensive.

A final remark is in order, before I close, regarding the welfare implications of what I have said about trade in services. Nothing that I have done here should be regarded as casting doubt on the potential for countries to gain from free trade, in services as well as goods. Even in the Case II example of section IV, where trade might be said to run counter to comparative advantage, there is still a very clear gain from trade for both the countries involved. 


\section{REFERENCES}

Deardorff, Alan U. (1979) "Weak Links in the Chain of Comparative Advantage," Journal of International Economics 9 (May), PP. 197-209.

Deardorff, Alan U. (1980) "The General Validity of the Law of Comparative Advantage," Journal of Political Economy 88 (October), PP. 941-957.

Deardorff, Alan $U$. (1982) "The General Validity of the Heckscher-Ohlin Theorem," American Economic Review 72 (September), PP. $683-694$.

Ethier, Wilfred J. and Lars E.0. Svensson (1983) "The Theorems of International Trade with Factor Mobility," Working Paper No. 1115, National Bureau of Economics Research (May).

Findlay, R. and H. Grubert (1959) "Factor Intensities, Technological Progress and the Terms of Trade," Oxford Economic Papers 11, PP. 111-121.

Helpman, Elhanan (1984) "A Simple Theory of International Trade with Multinational Corporations," Journal of Political Economy 92 .

Helpman, Elhanan and Paul R. Krugman (1984) Increasing Returns, Imperfect Competition, and International Trade, in process (May). 
Hill, T.P. (1977) "On Goods and Services," Review of Income and Wealth 23 (December), pp. 315-338.

Hindley, Brian and Alasdair Smith (1984) "Comparative Advantage and Trade in Services," presented at a Conference on Restrictions on Transactions in the International Market for Services, Wiston House, West Sussex, England, May 30-June 2.

Markusen, James R. (1984) "Multinational, Multi-Plant Economies, and the Gains from Trade," Journal of International Economics 16 .

Stern, Robert M. (1984) "Global Dimensions and Determinants of International Trade and Investment in Services," in process. 


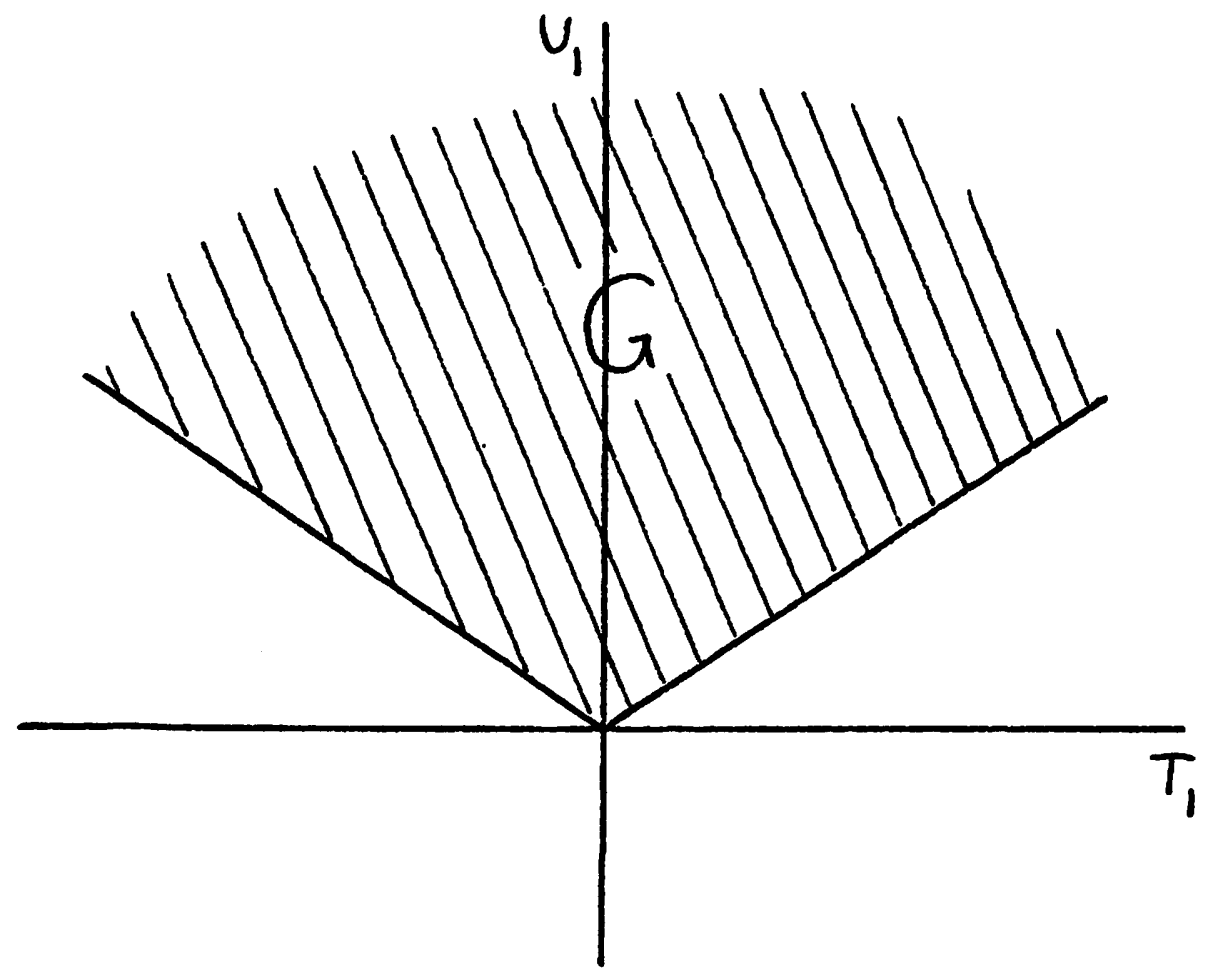

Figure 1 

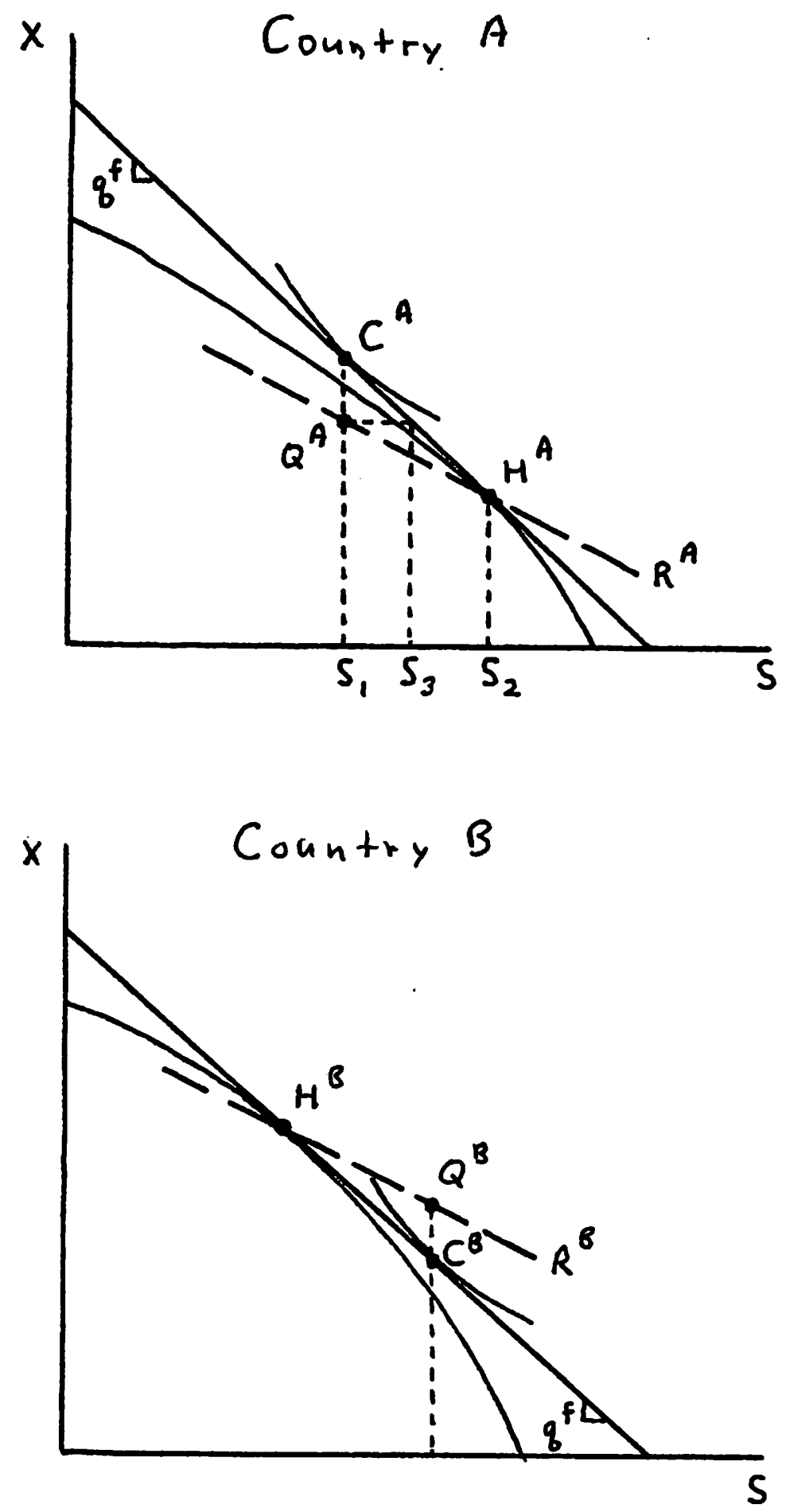

Figure 2 

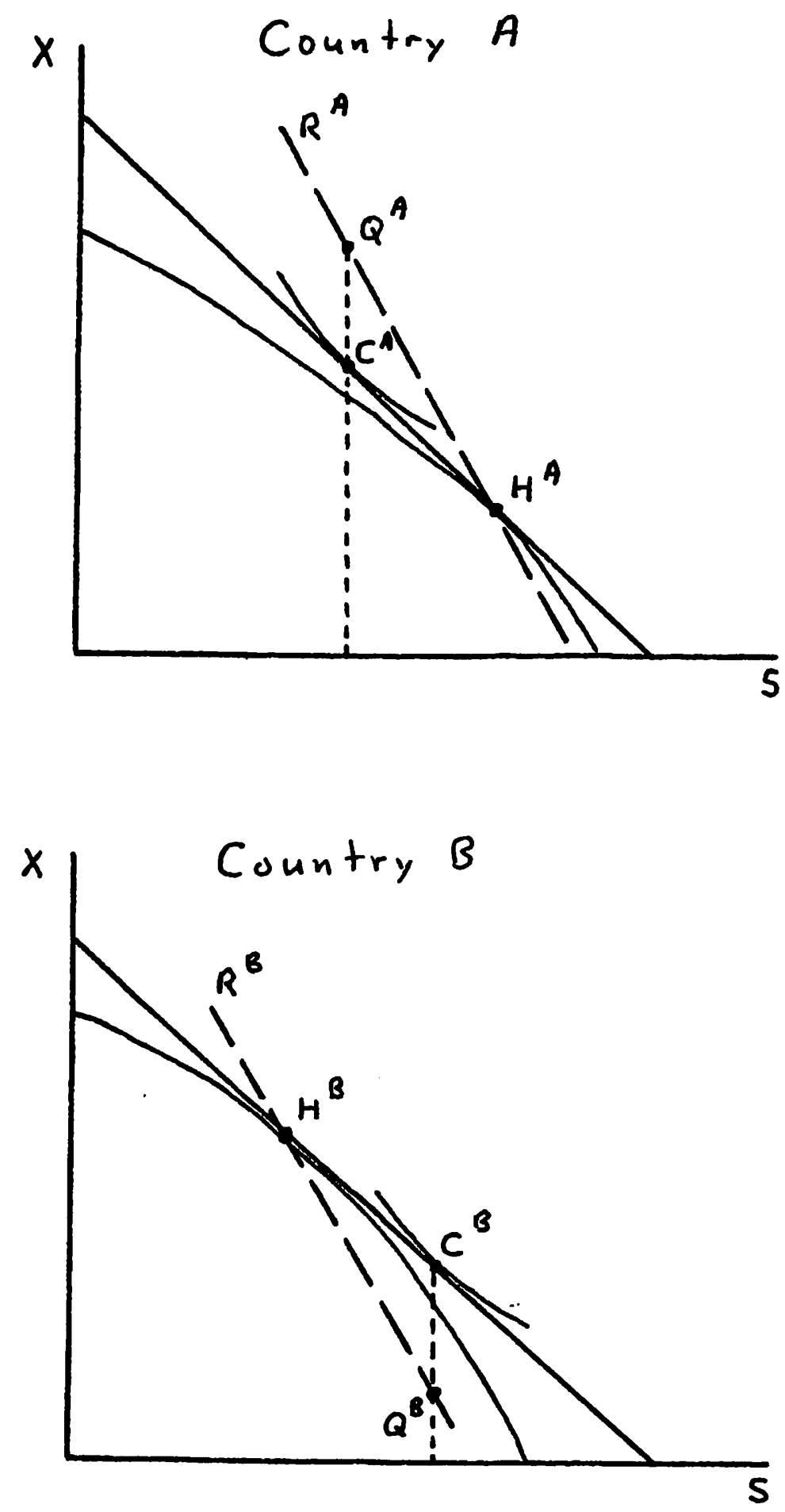

Figure 3 


\section{1}

$8101 \mathrm{C}$

$8102 \mathrm{C}$

$8103 C$

$8104 C$

$8105 C$

$8106 C$

$8107 C$

8108C D SU

8109 C D S

$8110 c$

$8111 \mathrm{C}$

$8201 C$

$8202 C$

$8203 C$

$8204 C$

$8205 C$

$8206 C$

$8207 \mathrm{C}$.

$8208 C$

$8209 C$ DSU

Markusen, James R. Factor Movements and Comnodity Trade as Compliments: A Arvey of Some Cases.

Conlon, R.M. Comparison of Australian and Canadian Manufacturing Industries: Some Empirical Evidence.

Conlon, R.M. The Incidence of Transport Cost and Tariff Protection: Some Australian Evidence.

Laidler, David. On the Case for Gradualism.

Wirick, Ronald G. Rational Expectations and Rational stabilization Policy in an Open Economy

Mansur, Ahsan and John Whalley Numerical secification of Applied General Equilibrium Models: Estimation, Calibration, and Data.

Burgess, David F., Energy Prices, Capital Formation, and Potential GNP

Jimenez, E. and Douglas Heare. Husing Consumption and Income in the Low Income Urban setting: Estimates from Panel Data in El Slvador

Whalley, John Labour Migration and the North-South Debate

Manning, Richard and John McMillan Government Expenditure and Comparative Advantage

Freid, Joel and Peter Howitt Why Inflation Reduces Real I nterest Rates

$\underline{1982}$

Manning, Richard and James R. Markusen Dynamic Non- Substitution and Long Run Production Possibilities

Feenstra, Robert and Ken Judd Tariffs, Technology Transfer, and Welfare

Ronald W. Jones, and Douglas D. Purvis: International Differences in Response to Common External hocks: The Role of Purchasing Power Parity

James A Brander and Barbara J. Spencer: Industrial strategy with Committed Firms

Whalley, John, The North-South Debate and the Terms of Trade: An Applied General Equilibrium Approach

Roger Betancourt, Christopher Clague, Arvind Panagariya CAPI TAL UTILIZATI ON IN GENERAL DOUIIIIBRIUM

Mansur, Ahsan $H$ On the Estimation of Import and Export Demand Elasticities and Elasticity Pessimism.

Whalley, J. and Randy Wigle PRICE AND QUANTITY RIGIDITIES IN ADJUSTAENT TO TRADE POLICY CHANGES: ALTERNATIVE FORMULATIONS AND INITIAL CALCULATIONS

Jimenez, E. SQUATTINC AND COMMUNITY ORGANIZATION IN DEVELOPING COUNTRIES:

A CONCEPTUAL FRAMEWORK 
$8210 \mathrm{C}$ Grossman, G.M. INTERNATIONAL COMPETITION AND THE UNIONIZED SECTOR

$8211 C$ La1dler,D. FRIEDMAN AND SCHWARTZ ON MONETARY TRENDS - A REVIEW ARTICLE 8212C Imam, M.H. and Whalley, J. INCIDENCE ANALYSIS OF A SECTOR SPECIFIC MINIMUM
WAGE IN A TWO SECTOR HARRIS-TODARO MODEL. 8213C Markusen, J.R. and Melvin, J.R. THE GAINS FROM TRADE THEOREM WITH INCREASING
RETURNS TO SCALE. 8214C INDUSTRIAL ORGANIZATION AND THE GENERAL EQUILIBRIUM COSTS OF PROTECTION IN
SMALL OPEN ECONOMIES.

8215C LaldIer, D. DID MACROECONOMICS NEED THE RATIONAL EXPECTATIONS REVOLUTION?

8216C Whalley, J. and WIgle, R. ARE DEVELOPED COUNTRY MULTILATERAL TARIFF REDUCTIONS NECESSARILY BENEFICIAL FOR THE U.S.?

8217C Bade, R. and Park1n, M. IS STERLING M3 THE RIGHT AGGREGATE?

8218C Kosch, B. FIXED PRICE EỌUIIIBRIA IN OPEN ÉCONOMIES.

1983

8301C Kimbell, L.J. and Harrison, G.W. ON THE SOLUTION OF GENERAL EQUILIBRIUM
MODELS.

8302C Melvin, J.R. A GENERAL EquILIBRIUM ANALYSIS OF'.CANADIAN OIL POLICY. 8303C Markusen, J.R. and Svensson, L.E.O. TRADE IN GOODS AND FACTORS WITH
INTERNATIONAL DIFFERENCES IN TECHNOLOCY.

8304C Mohamad, S: Whalley, J. RENT SEEKING IN INDIA: ITS COSTS AND POLICY
SIGNIFICANCE.

8305C DSU Jimenez, E. TENURE SECURITY AND URBAN SỌUATTING.

8306C Parkin, M. WHAT CAN MACROECONOMIC THEORY TELL US ABOUT THE WAY DEFICITS
SHOULD BE MEASURED.

8307C Parkin, M. THE INFLATION DEBATE: AN ATTEMPT TO CLEAR THE AIR.

8308C Wooton, I. LABOUR MIGRATION IN A MODEL OF NORTH-SOUTH TRADE.

8309C Deardorff, A.V. THE DIRECTIONS OF DEVELOPING COUNTRIES TRADE: EXAMPLES
FROM PURE THEORY.

8310C Manning, R. ADVANTAGEOUS REALLOCATIONS AND MULTIPLE EQUILIBRIA: RESULTS
FOR THE THREE-AGENT TRANSFER PROBLEM. 
$8311 \mathrm{C}$ DSU Mohammad, S. and Whalley, J. CONTROLS AND THE INTERSECTORAL TERMS OF TRADE IN INDIA.

8312C Brecher, Richard A. and Choudhri, Ehsan U. NEW PRODUCTS AND THE FACTOR CONTENT OF INTERNATIONAL TRADE.

8313C Jones, R.W., Neary, J.P. and Ruane, F.P. TWO-WAY CAPITAL FLOWS: CROSSHAULING IN A MDDEL OF FOREIGN INVESTMENT.

$8314 C$ DSU Follain, J.R. Jr, and Jimenez, E. THE DEMAND FOR .HOUSING CHARACTERISTICS IN DEVELOPING COUNTRIES.

8315C Shoven, J.B. and Whalley, J. APPLIED GENERAL EQUILIBRIUM MODELS OF TAXATION AND INTERNATIONAL TRADE.

8316C Boothe, Paul and Longworth David. SOME IRRECULAR REGULARITIES IN THE CANADIAN/U.S. EXCHANGE MARKET.

$8317 \mathrm{C}$ Hamilton, Bob and Whalley, John. BORDER TAX ADJUSTMENTS AND U.S. TRADE.

8318C Neary, J. Peter, and Schweinberger, Albert G. FACTOR CONTENT FUNCTIONS AND THE THEORY OF INTERNATIONAL TRADE.

8319C Veall, Michael R. THE EXPENDITURE TAX AND PROGRESSIVITY.

8320C Melvin, James R. DOMESTIC EXCHANGE, TRANSPORTATION COSTS AND INTERNATIONAL TRADE.

8321C Hamilton, Bob and Whalley, John. GEOGRAPHICALLY DISCRIMINATORY TRADE ARRANGEMENTS.

8322C Bale, Harvey Jr. INVESTMENT FRICTIONS AND OPPORTUNITIES IN BILATERAL U.S.-CANADIAN TRADE RELATIONS.

8323C Wonnacott, R.J. CANADA-U.S. ECONOMIC RELATIONS--A CANADIAN VIEW.

$8324 \mathrm{C}$. Stern, Robert M. U.S.-CANADIAN TRADE AND INVESTMENT FRICTIONS: THE U.S. VIEN.

8325C Harrison, Glenn, H. and Kimbell, Larry, J. HOW ROBUST IS NUMERICAL GENERAL EQQUILIBRIUM ANALYSIS?

8326C Wonnacott, R.J. THE TASK FORCE PROPOSAL ON $\Lambda U T O$ CONTENT: WOULD THIS SIMPLY EXTEND THE AUTO PACT, OR PUT IT AT SERIOUS RISK?

8327C Bradford, James C. CANADIAN DEFENCE TRADE WITH THE U.S. Conk1in, David. SUBSIDY PACTS.

Rugman, $\Lambda$ lan M. THE BEHAVIOUR OF U.S. SUBSIDARIES IN CANADA:

IMPLICATIONS FOR TRADE AND INVESTMIENTS. 
8328 Boyer, Kenneth D. U.S.-CANADIAN TRANSPORTATION ISSUES. $8329 \mathrm{C}$ Bird, Richard M. and Brean, Donald J.S. CANADA-U.S. TAX RELATIONS:
ISSUES AND PERSPECTIVES. 8330C Moroz, Andrew R. CANADA-UNITED STATES AUTOMOTIVE TRADE AND TRADE
POLICY ISSUES.

$8331 \mathrm{C}$ Grey, Rodney de C. and Curt1s, John. INSTITUTIONAL ARRANGEMENTS FOR U.S.-CANADIAN NEGOTIATIONS. PART I: CANADA-U.S. TRADE AND ECONOMIC . ISSUES: DO WE NEED A NEW INSTITUTION? PART II: INSTITUTIONAL ARRANGEMENTS FOR MANAGING THE CANADA-U.S. ECONOMIC RELATIONSHIP.

\section{$\underline{1984}$}

8401C Harrison, Glenn W. and Manning, Richard.. BEST APPROXIMATE AGGREGATION OF INPUT-OUTPUT SYSTEMS.

8402C Parkin, Michael. CORE INFLATION: A REVIEW ESSAY.

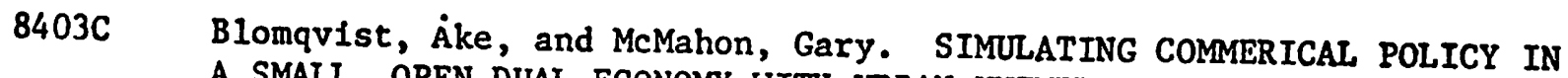
A SMALL, OPEN DUAL ECONOMY WITH URBAN UNEMPLOYMENT: A GENERAL EQUILIBRIUM APPROACH.

8404C Wonnacott, Ronald. THE THEORY OF TRADE DISCRIMINATION: THE MIRROR IMAGE OF VINERIAN PREFERENCE THEORY?

8405C Whalley, John. IMPACTS OF A $50 \%$ TARIFF REDUCTION IN AN EIGHT-REGION GLOBAL TRADE MODEL. 8406C Harrison, Glenn W. A GENERAL EQUILIBRIUM ANALYSIS OF TARIFi
REDUCTIONS.

8407C Horstmann, Ignatius and Markusen, James R. STRATEGIC INVESTMENTS AND THE DEVELOPMENT OF MULTINATIONALS.

8408C Gregory, Allan W. and McCurdy, Thomas H. TESTING THE UNBIASEDNESS HYPOTHESIS IN THE FORIARD FOREIGN EXCHANGE MARKET: A SPECIFICATION
ANALYSIS.

8409C Jones, Ronald H. and Kierzkowsk1, Henryk. NEIGHBORHOOD PRODUCTION STRUCTURES WITH APPLICATIONS TO THE THEORY OF INTERNATIONAL TRADE.

$8410 \mathrm{C}$ Weller, Paul and Yano, Makoto. THE ROLE OF FUTURES MARKETS IN INTERNATIONAL TRADE: A GENERAL EOUUILIBRIUM APPROACH.

$8411 \mathrm{C}$ Brecher, Richard A. and Bhagwati, Jagdish N. VOLUNTARY EXPORT RESTRICTIONS VERSUS IMPORT RESTRICTIONS: A WELFARE-THEORETIC COMPARISON. 
8412C Ethier, Wilfred J. ILLEGAL IMMIGRATION.

8413C Eaton, Jonathon and Gene M. Grossman. OPTIMAL TRADE AND INDUSTRIAL POLICY UNDER OLIGOPOLY.

$8414 \mathrm{C}$ Hooton, Ian. PREFERENTIAL TRADING AGREEMENTS - A $3 \times n$ MODEL.

8415C Parkin, Michael. DISCRIMINATJNG BETWEEN KEYNESIAN AND CLASSICAL THEORIES OF THE BUSINESS CXCLE; JAPAN 1967-1982

8416C Deardorff, Alan V. FIRless FIRwoes: HOW PREFERENCES CAN INTERFERE WITH THE THEOREMS OF INTERNATIONAL TRADE.

8417C Greenwood, Jeremy. NONTRADED GOODS, THE TRADE BALANCE, AND THE BALANCE OF PAYRENTS.

8418C Blomqvist, Ake and Sharif Mohammad. CONTROLS, CORRUPTION, AND COMPETITIVE RENT-SEEKING IN LDCs.

8419C Grossman, Herschel I. POLICY, RATIONAL EXPECTATIONS, AND POSITIVE ECONOMIC ANALYSIS.

$8420 \mathrm{C}$ Garber, Peter M. and Robert G. King. DEEP STRUCTURAL EXCAVATION? A CRITIOUE OF EULER EQUATION METHODS.

$8421 \mathrm{C}$ Barro, Robert J. THE BEHAVIOR OF U.S. DEFICITS.

8422C Persson, Torsten and Lars E.0. Svensson. INTERNATIONAL BORROWING AND TIME-CONSISTENT FISCAL POLICY.

8423C Obstfeld Maurice. CAPITAL CONTROLS, THE DUAL EXCHANGE RATE, AND DEVALUATION.

8424C Kuhn, Peter. UNION PRODUCTIVITY EFFECTS AND ECONOMIC EFFICIENCY.

8425C Hamilton, Bob and John Whalley. TAX TREATMENT OF HOUSING IN A DYNAMIC SEOUUENCED GENERAL EOUUILIBRIUM MODEL.

\$426C Hamilton, Bob, Shartf Mohammad, and John Whalley. RENT SEEKING AND THE NORTH-SOUTH TERMS OF TRADE.

8427C Adams, Charles and Jeremy Greenwood. DUAL EXCHANGE RATE SYSTEMS AND CAPITAL CONTROLS: AN INVESTIGATION.

8428 Loh, Choon Cheong and Michael R. Veall. A NOTE ON SOCIAL SECURITY AND PRIVATE SAVINGS IN SINGAPORE.

8429 Whalley, John. REGRESSION OR PROGRESSION: THE TAXING OUESTION OF INCIDENCE ANALYSIS.

3430 Kuhn, Peter. WAGES, EFFORT, AND INCENTIVE-COMPATIBILITY IN LIFE-CYCLE EMPLOYMENT CONTRACTS. 
8431 Greenwood, Jeremy and Kent P. Kimbrough. AN INVESTIGATION IN THE THEORY OF FOREIGN EXCHANGE CONTROLS.

8432 Greenwood, Jeremy and Kent P. Kimbrough. CAPITAL CONTROLS AND THE INTERNATIONAL TRANSMISSION OF FISCAL POLICY.

8433 : Nguyen, Trien Trien and John Whalley. EQ̣UILIBRIUM UNDER PRICE CONTROLS WITH ENDOGENOUS TRANSACTIONS COSTS.

8434 Adams, Charles and Russell S. Boyer. EFFICIENCY AND A SIMPLE MODEL OF EXCHANGE RATE DETERMINATION.

8435 Kuhn, Peter. UNIONS, ENTREPRENEURSHIP, AND EFFICIENCY.

8436 Hercowitz, Zv1 and Efraim Sadka. ON OPTTMAL CURRENCY. SUBSTITUTION POLICY AND PUBLIC PINANCE.

8437 Lenjosek, Gordon and John Whalley. POLICY EVALUATION IN A SMALL OPEN PRICE TAKING ECONOMY: CANADIAN ENERGY POLICIES.

8438 Aschauer, David and Jeremy Greenwood. MACROECONOMIC EFFECTS OF FISCAL POLICY.

8439C Hercowitz, Zvi. ON THE DETERMINATION OF THE EXTERNAL DEBT: THE CASE OF ISRAEL.

8440C Stern, Robert M. GLOBAL DIMENSIONS AND DETERMINANTS OF INTERNATIONAL TRADE AND INVESTMENT IN SERVICES.

8441C Deardorff, Alan V. COMPARATIVE ADVANTAGE AND INTERNATIONAL TRADE AND INVESTMENT IN SERVICES.

8442C Daly, Donald J. TECHNOLOGY TRANSFER AND CANADA'S COMPETITIVE PERFORMANCE.

8443C Grey, Rodney de C. NEGOTIATING ABOUT TRADE AND INVESTMENT IN SERVICES.

8444C Grossman, Gene $M$. and Carl Shapiro. NORMATIVE ISSUES RAISED BY INTERNATIONAL TRADE IN TECHNOLOGY SERVICES.

8445C Chant, John F. THE CANADIAN TREATMENT OF FOREIGN BANKS: A CASE STUDY IN THE WORKINGS OF THE NATIONAL TREATMENT APPROACH.

8446C Aronson, Jonathan D. and Peter F. Cowhey. COMPUTER, DATA PROCESSING, AND COMMUNICATION SERVICES. 